\title{
Malassezia pachydermatis: enzymes production in isolates from external ear canal of dogs with and without otitis
}

[Malassezia pachydermatis: produção de enzimas por amostras isoladas do conduto auditivo externo de cães com e sem otite]

\author{
S.D.A. Coutinho \\ Curso de Medicina Veterinária da Universidade Paulista - UNIP \\ Av. Dr. Altino Arantes, 1348 - Vila Clementino \\ 04042-005 - São Paulo, SP
}

\begin{abstract}
The relationship between production of enzymes and pathogenicity of Malassezia pachydermatis strains was studied. Thirty strains of $M$. pachydermatis isolated from dogs were used: 15 originating from animals with external otitis and 15 obtained from ears of asymptomatic dogs. The samples, obtained by introduction of a sterile swab into the auditory canal after cleaning the auricle with alcohol-ether solution, were seeded onto Sabouraud dextrose agar with chloramphenicol $(100 \mathrm{mg} / \mathrm{l})$ and were incubated at $37^{\circ} \mathrm{C}$ for up to two weeks. The colonies were identified according to their macro-and-micromorphology. All strains were investigated for the production of chondroitin-sulphatase, hyaluronidase, phospholipase and proteinase. Most of the strains showed a high production of the four enzymes. Statistical analysis did not show any differences in the enzymatic activity among the strains. $M$. pachydermatis originating in normal microbiota as well as in otic secretion from dogs with otitis could produce the four researched enzymes. Probably $M$. pachydermatis has other virulence factors that are involved in the parasitism.
\end{abstract}

Keywords: dog, Malassezia pachydermatis, enzymes, otitis, microbiota

\section{RESUMO}

Pesquisou-se a possível relação entre a produção de enzimas e a patogenicidade de Malassezia pachydermatis. Foram estudadas 30 cepas de M. pachydermatis provenientes de cães: 15 isoladas de animais com otite externa e 15 isoladas de condutos auditivos de animais assintomáticos. As amostras, obtidas pela introdução de uma zaragatoa no conduto auditivo, após limpeza do pavilhão auricular com solução de álcool-éter, foram semeadas em ágar Sabouraud dextrose acrescido de cloranfenicol (100mg/l) e incubadas a $37^{\circ} \mathrm{C}$ por até duas semanas. As colonias foram identificadas por meio de estudo macro e micromorfológico. As amostras isoladas foram investigadas quanto à produção das enzimas condroitina-sulfatase, hialuronidase, fosfolipase e proteinase. A maioria delas mostrou alta produção das quatro enzimas pesquisadas. A análise estatística não evidenciou diferenças na atividade enzimática entre as amostras testadas. M. pachydermatis, isolada como componente da microbiota sapróbia ou nos casos de otite externa, tem a capacidade de produzir as quatro enzimas. Provavelmente $\mathrm{M}$. pachydermatis apresenta outros fatores de virulência que estejam mais relacionados ao parasitismo.

Palavras-chave: cão, Malassezia pachydermatis, enzimas, otite, microbiota

Apoio financeiro: Vice-Reitoria de Pesquisa e Pós-Graduação da Universidade Paulista - UNIP Recebido para publicação em 20 de janeiro de 2003

Recebido para publicação, após modificações, em 3 de agosto de 2004

E-mail: selene@uol.com.br 


\section{INTRODUCTION}

The habitat of Malassezia pachydermatis is not completely known and the microorganism survives for only short periods in the environment (Gabal, 1988). However, it is known that the yeast is part of the mucosa and skin microbiota of mammals, and has been frequently isolated from the auditory canal and skin of healthy dogs and cats (Hajsig et al., 1990; Bond et al., 1995; Guillot and Bond, 1999) and from other domestic and wild animals (Guillot et al., 1994; Kuttin and Müller, 1994; Guillot and Bond, 1999).

Although $M$. pachydermatis is a commensal microorganism, some conditions may lead to its exacerbated development, causing disease. Predisposing host factors and an imbalance between microorganism populations are fundamental for the multiplication of Malassezia sp (Bond et al., 1996). The high isolation rates of these organisms could be explained by factors as humidity, breed, age, pendulous ears, season, intercurrent diseases (Duarte et al., 2001; Kumar et al., 2003; Machado et al., 2003).

However, although malasseziosis represents an important disease in clinical practice involving small animals, especially dogs, the virulence factors and pathogenesis of the diseases caused by this yeast are still unknown (Guillot and Bond, 1999).

The production of enzymes by microorganisms has been related to their pathogenicity. In this respect, the production and secretion of exoenzymes have been established as the main factor of virulence for some bacteria (Schaechter et al., 1993).

Based on observations made on yeasts of the genus Candida, Coutinho and Paula (2000) demonstrated that samples of $M$. pachydermatis isolated from the external auditory canal and skin of dogs with malasseziosis are also able to produce these enzymes. However, the authors did not perform any experiment to determine the relationship between enzyme production and pathogenicity.

Therefore, the objective of the present study was to compare strains of $M$. pachydermatis isolated from cerumen of asymptomatic dogs and otic secretion from dogs with external otitis, regarding the production of the enzymes chondroitin-sulphatase, hyaluronidase, phospholipase and proteinase, in order to determine differences in the production of these enzymes that are related to the origin of the samples, i.e., normal microbiota or otitis.

\section{MATERIAL AND METHODS}

Thirty isolates of $M$. pachydermatis from dogs were studied, 15 obtained from cerumen of asymptomatic dogs and 15 from otic secretions of animals with external otitis. The animals with otitis presented otalgia and/or erythema, hyperplasia of the ear canals, pruritus, dark secretion with characteristic odor. It was not determined if $M$. pachydermatis was primary or secondary pathogen in that process.

The production of four enzymes by $M$. pachydermatis was investigated by employing the same culture media and techniques as described for checking the production of proteinase (Rüchel et al., 1982), phospholipase (Price et al., 1982), hyaluronidase and chondroitin-sulphatase (Shimizu et al., 1995) by C. albicans. These methods were also used to verify the production of those enzymes by $M$. pachydermatis (Coutinho and Paula, 2000).

Incubation of the plates was performed at $37^{\circ} \mathrm{C}$, the optimum temperature for growth of $M$. pachydermatis (Slooff, 1974). For the production of proteinase the readings were taken after 24 , $48,72,96 \mathrm{~h}$ and after 7 days. For the production of phospholipase the readings were done after 48, 72, 96h and after 7, 9, 11 and 14 days. For chondroitin-sulphatase and hyaluronidase the readings were taken after $48 \mathrm{~h}$ and 11 days, respectively.

The formation of a halo (zone of precipitation) around the colony was considered to indicate enzyme production. The enzymatic activities were measured in terms of the ratio of colony diameter to the total diameter of colony plus the zone of precipitation, as suggested by Price et al. (1982) for the production of phospholipase by $C$. albicans, and employed for $M$. pachydermatis by Coutinho and Paula (2000). Therefore, phospholipase $=1.00$ would be a negative strain; phospholipase $<1.00$ and $\geq 0.64$ would be a 
positive strain and phospholipase $<0.64$ would be a strongly positive strain for the production of the enzymes.

In order to analyse the results obtained, the tests herein described were applied; the rejection level of the null hypothesis was fixed ( $\alpha \leq 0.05)$.

Variance analyses were utilized to compare the two groups (dogs with otitis and asymptomatic dogs) for production of the enzymes. Variance analysis-one factor (production of enzyme) was used in the research of condroitin-sulfatase e hialuronidase and variance analysis-double factor (production of enzyme and interval readings) was applied when studying phospholipase and proteinase. When statistical differences were found (interval readings), the Tukey test was used (Zar, 1996; Dretzke and Heilman, 1998).

\section{RESULTS AND DISCUSSION}

Most strains showed a high production of enzymes, with chondroitin-sulphatase, hyaluronidase, phospholipase, and proteinase $\leq 0.64$ (Table 1). No significant differences were observed between the two groups.

Table 1. Production of chondroitin-sulphatase (after 48 hours), hyaluronidase (after 11days), phospholipase (after 7 days) and proteinase (after 48 hours) by isolates of Malassezia pachydermatis from dogs with otitis and ear canal of asymptomatic dogs

\begin{tabular}{|c|c|c|c|c|c|c|c|c|}
\hline & \multirow{2}{*}{\multicolumn{2}{|c|}{$\begin{array}{l}\text { Chondroitin-sulphatase } \\
(\mathrm{Cz})\end{array}$}} & \multirow{2}{*}{\multicolumn{2}{|c|}{$\begin{array}{c}\text { Hyaluronidase } \\
(\mathrm{Hz})\end{array}$}} & \multirow{2}{*}{\multicolumn{2}{|c|}{$\begin{array}{l}\text { Phospholipase } \\
(\mathrm{Pz})\end{array}$}} & \multicolumn{2}{|c|}{$\begin{array}{l}\text { Proteinase } \\
\text { (Prz) }\end{array}$} \\
\hline & & & & & & & 48 & \\
\hline & $\begin{array}{l}\text { Normal } \\
\text { microbiota }\end{array}$ & Otitis & $\begin{array}{c}\text { Normal } \\
\text { microbiota }\end{array}$ & Otitis & $\begin{array}{l}\text { Normal } \\
\text { microbiota }\end{array}$ & Otitis & $\begin{array}{l}\text { Normal } \\
\text { microbiota }\end{array}$ & Otitis \\
\hline & 0.24 & 0.24 & 0.54 & 0.65 & 0.43 & 0.33 & 0.36 & 0.67 \\
\hline & 0.31 & 0.20 & 0.71 & 0.65 & 0.44 & 0.39 & 0.44 & 0.50 \\
\hline & 1.00 & 0.27 & 0.71 & 0.58 & 0.46 & 0.39 & 0.30 & 0.50 \\
\hline & 1.00 & 0.33 & 0.55 & 0.63 & 0.43 & 0.40 & 0.25 & 0.40 \\
\hline & 0.31 & 0.31 & 0.67 & 0.43 & 0.44 & 0.44 & 0.30 & 0.40 \\
\hline & 0.31 & 0.26 & 0.53 & 0.43 & 0.43 & 0.46 & 0.40 & 0.30 \\
\hline & 0.33 & 0.25 & 0.46 & 0.50 & 0.47 & 0.50 & 0.30 & 0.57 \\
\hline & 0.31 & 0.24 & 0.60 & 0.53 & 0.33 & 0.46 & 0.50 & 0.57 \\
\hline & 0.29 & 0.33 & 0.71 & 0.54 & 0.40 & 0.41 & 1.00 & 0.33 \\
\hline & 0.33 & 0.31 & 0.64 & 0.73 & 0.47 & 0.30 & 0.40 & 0.23 \\
\hline & 0.24 & 0.31 & 0.56 & 0.50 & 0.47 & 0.41 & 0.40 & 0.40 \\
\hline & 0.28 & 0.28 & 0.48 & 0.57 & 0.40 & 0.35 & 0.33 & 0.30 \\
\hline & 1.00 & 1.00 & 0.71 & 1.00 & 0.79 & 0.46 & 0.27 & 0.20 \\
\hline & 0.60 & 0.31 & 0.80 & 0.52 & 0.37 & 0.53 & 0.33 & 0.33 \\
\hline & 0.28 & 0.28 & 0.83 & 0.50 & 0.40 & 0.44 & 0.40 & 0.33 \\
\hline Mean & 0.46 & 0.33 & 0.63 & 0.58 & 0.45 & 0.42 & 0.40 & 0.40 \\
\hline
\end{tabular}

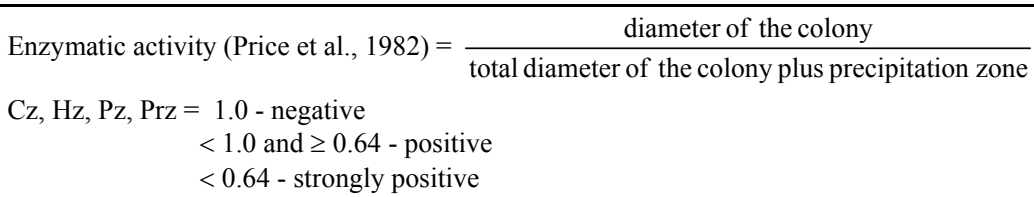

Final readings of chondroitin-sulphatase and hyaluronidase were obtained after $48 \mathrm{~h}$ and 11 days, respectively. These intervals were found to permit the best readings in a pilot assay, in which the plates were discarded after they were submitted to the action of acetic acid for 24,48 , 72 and 96h, and 5, 7, 11 and 14 days. In a similar study, Coutinho and Paula (2000) obtained the best readings for the production of these enzymes by $M$. pachydermatis at 7 days. In the present experiment, this interval was not adequate because the halos were diffuse and difficult to interpret.

Intervals of $48 \mathrm{~h}$ and 7 days were adopted for the production of proteinase and phospholipase, respectively. The production of proteinase was tested at 24, 48, 72 and $96 \mathrm{~h}$ and 7 days, with the 
best readings being obtained at 48 and $72 \mathrm{~h}$ (data not shown). With respect to phospholipase, its production was tested at 48, 72 and $96 \mathrm{~h}$, and 7, 9, 11 and 14 days, with the readings taken from 7 days onward being significantly higher than those obtained for the previous intervals (data not shown). The best intervals thus obtained for phospholipase agree with those reported by other investigators, who recommended that readings be performed within an interval of 7 to 10 days (Riciputo et al., 1996; Coutinho and Paula, 2000).

Although the functions of most enzymes produced by microorganisms are more related to nutrition and metabolism than to playing a role in infectious processes, there is no doubt that in the case of various bacteria and yeasts certain enzymes are closely associated with the pathogenicity of the strains (Mims, 1987).

The main connective tissue polysaccharides are glycosaminoglycans, macromolecules consisting of large and linear subunits of disaccharide polymers. Among them, the most important are hyaluronic acid and chondroitin-sulphate, the basic components of the non-cellular matrix of connective tissue. Because of their depolymerizing action on these substances, hyaluronidase and chondroitin-sulphatase are considered to be virulence factors of dissemination and penetration, facilitating the dispersal of infectious microorganisms (Schaechter et al., 1993).

In the present experiment, $M$. pachydermatis was able to produce chondroitin-sulphatase and hyaluronidase irrespective of its origin, i.e., otitis or normal microbiota, suggesting that these enzymes are not a determining factor in the infectious processes caused by this yeast.

To facilitate host tissue invasion, some microorganisms produce hydrolytic enzymes that destroy or derange membrane constituents, leading to membrane dysfunction or rupture (Ghannoum and Abu-Elteen, 1990). Cell membranes and membrane-containing internal vesicles consist of a double layer of phospholipids interspersed with proteins. Therefore, microorganisms that produce proteinase and/or phospholipase can hydrolyze the peptide bonds at these sites, introducing "pores" in the membranes and dismantling all cellular functions and favouring tissue invasion, with these enzymes functioning as virulence factors (Fawcett, 1995; Mushin et al., 1997).

The production of phospholipases has been demonstrated for different species of the genus Malassezia (Riciputo et al., 1996; Coutinho and Paula, 2000; Mancianti et al., 2000). Riciputo et al. (1996) reported that these enzymes are more frequently produced by strains ( $M$. furfur) isolated from patients with lesions than by those isolated from healthy individuals. However, these authors only tested two strains obtained from healthy individuals, which is a very small sample.

Mancianti et al. (2000) verified that $M$. pachydermatis isolates from dogs and cats showed a high enzymatic activity, with the production of 15 different enzymes. Although these authors suggested that the production of these enzymes might play a pathogenic role, the used protocol did not permit such conclusions.

This is the first report showing the production of these four enzymes by $M$. pachydermatis strains derived from normal microbiota. However, no differences in the production of proteinase and phospholipase by $M$. pachydermatis were observed between samples obtained from otic secretion and cerumen, reinforcing that the production of the enzymes studied is more related to the nutritional supply of the yeast in its environment than to being a virulence factor itself.

Canine otitis can be caused by other microorganisms, specially bacteria, that can modified the microenvironment of the ear auditory canal (Kumar et al., 2002; Machado et al., 2003; Nobre et al., 2001). Those changes are a predisposing factor to malasseziosis (Kowalski, 1988). Nevertheless, one of the most important aspects observed in this project is that the isolates of normal microbiota produce the four researched enzymes, showing that the enzymes production is not related to a previous infection.

Other virulence factors of $M$. pachydermatis seem to participate in the pathogenesis of this microorganism in host tissues. Further studies in this area should be encouraged since a better understanding of the host-parasite relationship 
would permit more adequate preventive and therapeutic measures in cases of malasseziosis.

\section{REFERENCES}

BOND, R.; FERGUSON, E.A.; CURTIS, C.F. et al. Factors associated with elevated cutaneous Malassezia pachydermatis populations in dogs with pruritic skin disease. J. Small Anim. Pract., v.37, p.103-107, 1996.

BOND, R.; SAIJONMAA-KOULUMIES, L.M.; LLOYD, D.H. Population sizes and frequency of Malassezia pachydermatis at skin and mucosal sites on health dogs. J. Small Anim. Pract., v.36, p.147-150, 1995.

COUTINHO, S.D.; PAULA, C.R. Proteinase, phospholipase, hyaluronidase and chondroitinsulphatase production by Malassezia pachydermatis. Med. Mycol., v.38, p.73-76, 2000.

DRETZKE, B.J.; HEILMAN, K.A. Statistics with Microsoft ${ }^{\circledR}$ Excel. New Jersey: Printice Hall, 1998. $164 \mathrm{p}$.

DUARTE, E.R.; BATISTA, R.D.; HAHN, R.C. et al. Factors associated with the prevalence of Malassezia species in the external ears of cattle from the state of Minas Gerais, Brazil. Med. Mycol., v.41, p.137-142, 2003

FAWCETT, D.W. Tratado de histologia. 12.ed. Nueva York: Interamericana - McGraw-Hill, 1995. 1044p.

GABAL, M.A. Preliminary studies on the mechanism of infection and characterization of Malassezia pachydermatis in association with canine otitis externa. Mycopathologia, v.104, p.93-99, 1988.

GHANNOUM, M.A.; ABU-ELTEEN, H. Pathogenicity determinants of Candida. Mycoses, v.33, p.265-282, 1990.

GUILLOT, J.; BOND, R. Malassezia pachydermatis: a review. Med. Mycol., v.37, p.295-306, 1999.

Guillot, J.; CHERMETTE, R.; GUÉHO, E. Prévalence du genre Malassezia chez les mammifères. J. Mycol. Méd., v.4, p.1-15, 1994.

HAJSIG, D.; HAJSIG, M.; SVOBODA-VUKOVIC, D. Nalazi kvasca Malassezia pachydermatis u zdravih macaka [Malassezia pachydermatis in health cats]. Vet. Arhiv, v.60, p.69-73, 1990.

KOWALSKI, J.J. The microbial environment of the ear canal in health and disease. Vet. Clin. North Am. Small Anim. Pract., v.18, p.743-754, 1988.
KUMAR, A.; SINGH, K.; SHARMA, A. Prevalence of Malassezia pachydermatis and other organisms in healthy and infected dogs ears. Israel Vet. Med. Assoc., v.57, p.145-148, 2002. Disponível em: http://www.isrvma.org/article/57_4_3.htm. Acessado em: 23 abr. 2004.

KUTTIN, E.S.; MÜLLER, J. The fungal flora of zoo animals' ears. Mycoses, v.37, p.59-60, 1994.

MACHADO, M.L.; APPELT, C.E.; FERREIRO, L.; GUILLOT, J. Otites e dermatites por Malassezia spp em cães e gatos. Clín. Vet., n.44, p.27-34, 2003.

MANCIANTI, F.; RUM, A.; NARDONI, S.; CORAZZA, M. Extracellular enzymatic activity of Malassezia spp isolates. Mycopathologia, v.149, p.131-135, 2000.

MIMS, C.A. The pathogenesis of infectious diseases. 3.ed. London: Academic, 1987. 342p.

MUSHIN, T.M.; AUBAID, A.H.; AL-DUBOON, A.H. Extracellular enzyme activities of dermatophytes and yeast isolates on solid media. Mycoses, v.40, p.465-469, 1997.

NOBRE, M.O.; CASTRO, A.P.; NASCENTE, P.S. et al. Occurrency of Malassezia pachydermatis and other infectious agents as cause of external otitis in dogs from Rio Grande do Sul State, Brazil (1996/1997). Braz. J. Microbiol., v.32, p.245-249, 2001.

PRICE, M.F.; WILKINSON, I.D.; GENTRY, L.O. Plate method for detection of phospholipase activity in Candida albicans. Sabouraudia, v.20, p.7-14, 1982.

RICIPUTO, R. M.; OLIVERI, S.; MICALI, G. et al. Phospholipase activity in Malassezia furfur pathogenic strains. Mycoses, v.39, p.233-235, 1996.

RÜCHEL, R.; TEGELER, R.; TROST, M. A comparison of secretory proteinases from different strains of Candida albicans. Sabouraudia, v.20, p.233244, 1982.

SCHAECHTER, M.; MEDOFF, G.; EISENSTEIN, B.I. Mechanisms of microbial disease. 2.ed. Baltimore: Williams \&Wilkins, 1993. 973p.

SHIMIZU. M.T.; JORGE, A.O.C.; UNTERKIRCHER, C.S.; et al. Hyaluronidase and chondroitin sulphatase production by different species of Candida. J. Med. Vet. Mycol., v.33, p.27-31, 1995.

SLOOFF, W.C. Genus Pityrosporum. In: LODDER, J. (Ed.). The yeasts: a taxonomic study. 3. Amsterdam: North-Holland Publ. Co., 1974. p.1167-1186.

ZAR, J.H. Biostatistical analysis. 3.ed. New Jersey: Practice Hall, 1996. 662p. 